\title{
Impact of Service Quality on Customer Satisfaction in Insurance Companies: A Study Conducted on Wolaita Zone
}

\author{
Addis Alemayehu (MBA) \\ Department of Management, Wolaita Sodo University, Wolaita Sodo,Ethiopia \\ Dawit Dalega (MBA) \\ Department of Management, Wolaita Sodo University, Wolaita Sodo,Ethiopia
}

\begin{abstract}
Insurance industry should become one part of solution of sustainable economic growth in the future, however, in order to retain and keep more investors and business owners, Insurance companies must have a greater service quality to satisfy and more wide range of different customer satisfactions regarded to insurance service. The objective of this study was investigating the impact of service quality on customer satisfaction in the insurance companies of Wolaita Zone. In order to do this, a causal cross sectional research study was conducted. A sample of 352 customers was selected using cluster sampling technique. For the purpose of the study primary data were collected from customers using likert scale based questionnaire, then the data were analyzed using descriptive statistics and inferential statistics.SPSS software 20.00 was used to analyze the primary data.Findings from the analysis revealed that out of the five dimensions of the SERVQUAL dimension three i.e., tangibles, reliability, Assurance and empathy had high significant impact on customer satisfaction in insurance companies in Wolaita zone.

Keywords: Service quality, Tangibility, Reliability, Responsiveness, Assurance, Empathy, and customer satisfaction.

DOI: $10.7176 / \mathrm{JMCR} / 63-01$

Publication date: December $31^{\text {st }} 2019$

\section{Introduction}

The current business environment is become competitive and challenged than before. With multidimensional challenges and demand of globalization, the organizations were forced to re-engineer their products and systems to improve the service quality and remain competitive, (Yasin et al., 2004, Rodie and Martin, 2001).

Due to intangible nature of services it is difficult for the firms to analyses how the customers perceive and evaluate the desired outcome of the service quality (Zeithaml, 1981). As customer evaluate their level of satisfaction by experimented the service quality, satisfaction with services is related to conformation or disconfirmation of expectations (Smith and Houston 1982). The issue of highest priority today involves understanding the impact of service quality on profit and other financial outcomes of the organization (Zeithaml et al., 1996).

As per Research by Oliver (2009) Organizations were increasingly become customer focused and were driven by customer demands. It is become equally challenged to satisfy and to preserve customer loyalty. It suggests that both service quality and customer satisfaction were two distinct but related constructs. It is particularly true for the services firms where increased level of customer satisfaction results in profit maximization. Therefore experts say that customer satisfaction should be the fundamental principle of all the service firms as it is the key indicator of firm's performance. As said by Sakthivel et al., (2005) Customer loyalty and customer satisfaction were proved to be the major determinant for long term survival and financial performance of the company (Jones and Sasser, 1995) also customers were considered as final adjudicators to judge the quality level of product and services offered.

This research mainly focuses on those improvements and processes to manage the process of quality services delivered to the final consumers and examines the relationship between service quality and customer satisfaction. To get the answers, research is conducted in a service industry (insurance) to gather information from practical life. For this purpose four leaded insurance companies found in Wolaita Zone, Southern Region Ethiopia, Medhin Insurance, Nile Insurance, Nyala Insurance, and Nice Insurance, in Wolaita Zone, SNNPRS, and Ethiopia.
\end{abstract}

\subsection{Statement of the Problem}

This study focused on the impact of service quality of customers satisfaction in the insurance companies of Ethiopia, According to Shifera (Thesis AAU, 2011), in the insurance industry, offered quality services is very important to create closer relationship with the entire customers. Quality of services has the power to create customer satisfaction. On the other hand poor quality of services results in customer dissatisfaction and customer defection by going to other competitors. 
According to Collart (2010), one of the determinants of success of a firm is how the customers perceive the resulted service quality, as this is the key driver of perceived quality. It is the perceived value which determines customer satisfaction. Many firms included insurance industries begin to track their customers' satisfaction through measured their level of service quality perceived by their customers.

Now days the competition is tough and stiff, where a competition is cut throat, the issue of service quality and customer satisfaction were priority agenda of a business and the ever unsatisfied and increasing need and want of customer for better service day to day what determine the success and existence of the company in the universe is service quality. According to Almossawi (2001), service quality is very essential in insurance industry due to it provide high level of customer satisfaction and a key competitive advantages .

Previous study (Meaza, 2016) which were conducted on insurance company in the study area mainly focus on predictors of life insurance company in Wolaita zone. However, it is important to see the impact of service quality on customer satisfaction. Besides this and to the best knowledge of the researcher, there is no research done on impact of service quality on customer satisfaction in the study area so far. Therefore, this is the rational for researching this problem.

Therefore, the purpose of this research is to investigate and analyse the impact of service quality on customer satisfaction in insurance companies on Wolaita zone and to test the significance influence of service quality dimensions on customer satisfaction.

\subsection{Objective of the Study}

The general objective of this study is to investigate the impact of service quality on customer satisfaction in insurance companies in case of wolaita zone.

\section{Literature Review}

\subsection{Concepts of Insurance}

Basically, insurance services was a business that is to accepting insurances from the contract between an insurer and the insured where by the insurer undertakes to indemnify the assured against losses, which may result from the occurrence of specified events within specified periods. General insurance business can be subdivided into: motor, fire, accident, oil and gas, contractors' all risks and engineering risks; marine and credit insurance, bond and surety ship etc. This is a contract between the assurer and the assured whereby the assurer undertakes to pay benefits to the policy holder on the attainment of a specified event.

\subsection{The Concept of Service Quality}

The concept of service quality has been defined as the consumer's outlook or judgment of the overall excellence or superiority of the service. Perceived service quality results from comparisons by consumers of expectations with their perceptions of service delivered by the suppliers (Lewis et al., 1994; Takeuchi and Quelch, 1983; Zeithaml, 1988). It is argued that the key to ensuring good service quality perception is in meeting or exceeding what customers expect from the service. Thus, if perception of the actual service delivered by the supplier falls short of expectation, a gap is created which should be addressed through strategies that affect the direction either of expectations or perceptions, or both (Parasuraman et al., 1985; Zeithaml et al., 1990).

Customer expectations play an important role in creating satisfaction. Customers' expectations are consumers $^{\text {ee }}$ beliefs about the performance a product based on prior experience and communications. When companies fall short of those expectations, customers are dissatisfied. When companies exceed them, consumers are delighted. In both cases, customers are emotionally charged by their experience the delighted are more likely to be loyal, and the dissatisfied are more inclined to switch.( Gilbert, D. H. and Gary, L. F.(1999) .

\subsection{The SERVQUAL Model}

Parasuraman et al. (1988) released a widely distinguishes five set of service quality dimension (SERVQUAL). This service quality dimension was amongst the frequently applied and quoted elements in the writing works of service quality (Othman \& Owen, 2001). These dimensions namely tangibility, reliability, responsiveness, assurance and empathy have been applied in many service firms to measure quality performance.

Tangibility relate to material characteristics like gadgets, equipment and how staffs carry themselves (Seo, 2012).This component deals with the existence of the physical facilities and the perceived quality of the materials, personnel and equipment used by the service giver (Kandampully, 2007).

Reliability is defined as the dependability, consistency and accuracy with which the service is performed by the provider (Kandampully, 2007). It is about the business keeps its word. It is the ability to perform the promised service dependably and accurately or delivered its promises. (Zeithaml et al., 2006 p.117).

Responsiveness relates to the zeal in the service personnel to serve customers in a well-timed, effective fashion and it incorporates elements like cooperativeness, kindliness and tenderness of the service stuff (Kandampully, 2007). It is the desire of the service giver to be supportive and quick in rendered the service 
(Prayuhda \& Harsanto, 2014).

Assurance is the extent to which the service personnel stimulate faith and credence among the customers of the firm (Kandampully, 2007). It is the employees. Knowledge and courtesy and the service provider's ability to inspire trust and confidence. (Zeithaml et al., 2006 p.119). If the customers don't find the service and staff of the company pleasant, the chances of them returned back was slim (Delgado-Ballester, 2004).

Empathy has to do with the cared and individualized attention. Granted to customers besides the degree of understanding personnel manifests in relation to customer needs (Kandampully, 2007). It has been ascertained to be more desirable and significant in magnified the quality of service in industries where established relationships with customers and clients guarantees survival (Andaleeb\& Conquality, 2006). The likelihood of clients returned back to a company provided they were give special care and attention is very high (Delgado-Ballester, 2004).

\subsection{The effects of service quality on customers.}

Service quality can be demarcated as the difference between customer's expectations of service performance earlier to the service encounter and their perceptions of the service received (Asubonteng et al., 2014). Quality service has a positive effect on the bottom-line performance of a firm and thereby on the competitive advantages that could be gained from an improvement in the quality of the service offered so that the perceived service exceeds the service level desired by customers (Caruana, 2012; Chumpitaz, 2014). Performed according to the desired level is critical to the entire organization. Monitored, controlled and improved the quality, the service delivery issue is essential to the firms' market orientation.

\subsection{Hypothesis}

H1: Tangibility has a significant impact on the customer's satisfaction in insurance company in Wolaita zone.

$\mathbf{H}_{2}$ : Reliability has a significant impact on the customer's satisfaction in insurance company in Wolaita zone.

H3: Responsiveness has no impact on the customer's satisfaction in insurance company in Wolaita zone.

H4: Assurance has a significant impact on the customer's satisfaction in insurance company in Wolaita zone.

H5: Empathy has a significant impact on the customer's satisfaction in insurance company in Wolaita zone.

\section{Research Methodology}

This research was primarily causal cross sectional research because it aimed at examined the relationship between customer satisfaction as a dependent variable and, trust, service quality, responsiveness, variability, assurance and empathy as independent variables. To find out the relation of each independent variable with the dependent variable that makes the research type causal. A research is quantitative in nature. Total population for the study was the customers of nine insurance Companies. As the insurance Companies operate in similar environment i.e. Wolaita sodo area and they have similar characteristics due to that out of nine insurance companies four clusters insurance companies were randomly selected(medin insurance, nice insurance, nyala insurance and nile insurance) with total population of 2900 (cluster sample was taken). The researcher was used Yamane's (1967) to calculate sample size. A sample of 352 customers was selected using cluster sampling technique. the total sample size of the study or 352 customers assigned proportionally by the researcher to be taken from each insurance company. primary data were collected from customers using five point Likert scale ( $1=$ strongly disagree, $2=$ disagree, $3=$ neutral, $4=$ agree, $5=$ strongly agree) based questionnaire, then the data were analyzed using descriptive statistics and inferential statistics. SPSS software 20.00 was used to analyze the primary data.

\subsection{Mathematical Model of the study}

The dependent variable in this study was customer satisfaction. According to Kotler and Keller, 2009 Customer Satisfaction can also be a person's feelings of pleasure or disappointment that results from compared a product's perceived performance or outcome with their expectations Thus, here customer satisfaction was measured as dependent variable in this study. Different variables were expected to affect customer satisfaction in insurance industries. Among those variables there were five instructive variables that have been identified based on empirical reviews.

$\mathrm{SQ}=$ Service Quality

These are Tangibility (T), Responsiveness (R), Assurance (A), Reliability (Re), Empathy (E).

To sum up, the functional form of the model was as follows

$\mathbf{C S}=\boldsymbol{\beta}+\boldsymbol{\beta}_{1}, \mathrm{SQ}$

$\mathbf{C S}=\boldsymbol{\beta}+\boldsymbol{\beta}_{1} \mathbf{T}+\boldsymbol{\beta}_{2} \mathbf{R}+\boldsymbol{\beta}_{3} \mathrm{~A}+\boldsymbol{\beta}_{4} \mathrm{Re}+\boldsymbol{\beta}_{5} \mathrm{E}+\mathrm{U}$

Where $\mathrm{CS}=$ the dependent variable and $\mathrm{T}, \mathrm{R}, \mathrm{A}, \mathrm{Re}$ and $\mathrm{E}$ were the explanatory or independent variable.

SQ=Service Quality

$\beta$ is the intercept term. As usual, it gives the mean or average effect on CS of all the variables excluded from the model, although its Mechanical interpretation is the average value of CS when all explanatory variables 
were set equal to zero.

The coefficients $\beta_{1}-\beta_{5}$ were called the partial regression coefficients and $U$ is the stochastic disturbance term may well represent impact of service quality on customer's satisfaction but were not taken into account explicitly.

\section{Data Analysis and Interpretation}

\subsection{Pearson Correlation analysis}

Based on questionnaires which were filled by the customers of selected insurance companies, the following Correlation analysis was made.

Table 4.1 Correlation analyses between service quality dimension and customer satisfaction.

\begin{tabular}{|l|l|l|}
\hline Factors & Pearson correlation & Customer satisfaction \\
\hline \multirow{2}{*}{ Rangibility } & Sig(2-tailed) & .357 \\
\cline { 2 - 3 } & Pearson correlation & .000 \\
\cline { 2 - 3 } & Sig(2-tailed) & .466 \\
\hline \multirow{2}{*}{ Responsiveness } & Pearson correlation & .000 \\
\cline { 2 - 3 } & Sig(2-tailed) & .305 \\
\hline Essurance & Pearson correlation & .000 \\
\cline { 2 - 3 } & Sig(2-tailed) & .705 \\
\hline & Pearson correlation & .000 \\
\cline { 2 - 3 } & Sig(2-tailed) & .119 \\
\hline
\end{tabular}

Source own survey, 2018

Note: correlation is significant at the 0.01 level Sig (2-tailed)

The results of Pearson correlation analysis provided in the table 4.1 shows that Tangibility is significantly, positively correlated with customer satisfaction. The result indicates that, a coefficient of $.357^{* * a t} \mathrm{p}=0.000(\mathrm{r}=$ $\left..357^{* *}, \mathrm{p}<0.001\right)$ which shows that the two variables, independent $\&$ dependent variables that is Tangibility \& customer satisfaction are positively correlated (35.7\%). As the result of Pearson correlation analysis provided in table 4.1 shows that Reliability has significant and positive association with customer's satisfaction. The result shows a coefficient of $.466^{* *}$ at $\mathrm{P}=0.001\left(\mathrm{r}=.466^{* *}, \mathrm{P}<0.001\right)$ which shows that the contracts Reliability and customer satisfaction are correlated.

It is about the business keeps its word. It is the ability to perform the promised service dependably and accurately or delivered its promises. The result of Pearson correlation analysis provided in table 4.1 shows that Responsiveness is correctly correlated to customer's satisfaction. The result shows a coefficient of $.305^{* *}$ at $\mathrm{P}=0.001\left(\mathrm{r}=.305^{* *}, \mathrm{P}<0.001\right)$ which shows that the contracts Responsiveness and customer satisfaction are positively relationship (30.5\%). The study confirms that Responsiveness and customer satisfaction are definitely correlated with each other. The insurance customers prepare a friendly insurance, which is deliver prompt service to customer as promised to do something by certain time and without delay. Responsiveness is likely to have an important and positive effect on customer satisfaction in the insurance company Mengi (2009) also found that responsiveness is positively related to customer's satisfaction.

As the result of Pearson correlation analysis provided in table 4.1 also shows that Assurance have significant positive association with customer's satisfaction. The result shows a coefficient of .705**at $\mathrm{P}=0.001\left(\mathrm{r}=.705^{* * \mathrm{P}}<0.001\right)$ which shows that the contracts Assurance and customer satisfaction are interrelated. The coefficient of determination shows that there is a significant relationship of $(70.5 \%)$.

As the result of Pearson correlation analysis provided in table 4.1 shows that Empathy quality is positively correlated to customer's satisfaction. The result shows a coefficient of $0.119^{* *}$ at $\mathrm{P}=0.001\left(\mathrm{r}=.119^{* *}, \mathrm{P}<0.001\right)$ which shows that the contracts Empathy and customer satisfaction are significantly interrelated. The coefficient of determination shows that there is a positive relationship of $(11.9 \%)$.

According to this study there is a significant relationship between Empathy and customer satisfaction in the insurance company. The result shows that the ability to make the customer feel welcome, particularly by the contact staff. Chase et al. (2001), empathy is the provision of caring, individualized attention to customers. Fitzsimmons and Fitzsimmons (2001) posit that empathy includes approachability, sensitivity, and effort to understand the customer's needs. It is also pointed out empathy is significantly interrelated to customers satisfaction. 


\subsection{Model summary}

Table 4.2 Regression Model summary

\begin{tabular}{|l|l|l|l|l|}
\hline Multiple R & R Square & Adjusted R Square & Std. Error of the Estimate & Durbin-Watson \\
\hline .727 & .528 & .522 & .685 & 1.880 \\
\hline
\end{tabular}

Source own survey, 2018.

a. predictors:(Constant),Empathy, Reliability, Assurance, Tangibility, Responsiveness

b. Dependent Variable: Customer satisfaction

As the table 4.2 shows that Square of correlation coefficient of all factors share is $(72.7 \%)$ of factors of customer's satisfaction. Therefore, the researcher found that Tangibility, Reliability, Responsiveness, Assurance and Empathy shares $(72.7 \%)$ of service quality dimension on customer's satisfaction in insurance company in wolaita zone.

The adjusted $\left(\mathrm{R}^{2}\right)$ value indicates the loss of predictive power or shrinkage, the adjusted value tells us how much variance in customer satisfaction would be accounted for if the model had been derived from the population from which the sample was taken, the adjusted $\mathrm{R}^{2}$ gives some idea of how well our model generalizes and ideally its value to be the same, or very close to, the value of $\mathrm{R}^{2}$. In the table the difference for the final model is small (in fact the difference between the values is $(0.528-0.522)=0.011$ about $(1.1 \%)$. This shrinkage means that if the model were derived from the population rather than a sample it would account for approximately $(1.1 \%)$ less variance in the outcome. Therefore, the regression model results in significantly better service quality dimension on customers satisfaction than that of mean value of all service quality dimension of customers satisfaction.

4.3.Regression Coefficient value of the independent variables

Table 4.3 Regression Coefficient value of the independent variable

\begin{tabular}{|c|c|c|c|c|c|c|c|}
\hline & \multicolumn{2}{|c|}{$\begin{array}{c}\text { Unstandardized } \\
\text { Coefficient }\end{array}$} & \multirow{2}{*}{$\begin{array}{c}\begin{array}{c}\text { Standardized } \\
\text { Coefficient }\end{array} \\
\text { Beta } \\
\end{array}$} & \multirow[t]{2}{*}{$\mathrm{T}$} & \multirow[t]{2}{*}{ Sig. } & \multirow[t]{2}{*}{ Hypotheses } & \multirow[t]{2}{*}{ Result } \\
\hline & $\beta$ & Std.error & & & & & \\
\hline Constant & .972 & .203 & & 4.794 & .000 & & \\
\hline Tangibility & .141 & .058 & .119 & 2.430 & .016 & H1 & accepted \\
\hline Reliability & .114 & .046 & .119 & 2.499 & .013 & $\mathrm{H} 2$ & accepted \\
\hline Responsiveness & .013 & .055 & .012 & .237 & .812 & $\mathrm{H} 3$ & rejected \\
\hline Assurance & .708 & .049 & .640 & 14.296 & .000 & $\mathrm{H} 4$ & accepted \\
\hline Empathy & .161 & .047 & .145 & 3.448 & .001 & $\mathrm{H} 5$ & accepted \\
\hline
\end{tabular}

Source own survey, 2018

a. Dependent variable customer satisfaction

The table 4.3 shows that, all the explanatory variables included in this study can significantly explain at $95 \%$ confidence level to the variation on the dependent variable. Thus, the largest influence on the customer satisfaction is from the Assurance (.640), Empathy (.145), and the next is Tenability and Reliability with the beta value of (.119). The importance of variables can be analysed using $\mathrm{T}$ value also which states that Assurance is higher $\mathrm{T}$ value that means Assurance is the most important predictor of customer satisfaction for insurance companies in Wolaita zone. On the other hand Responsiveness having significance value more than one significance level i.e. .05 is insignificant in predictor of customer's satisfaction of insurance company in Wolaita zone.

Meanwhile Table 4.3 also indicates that Assurance, Empathy, Tenability and Reliability have significantly effect on customer's satisfaction because their significant values were less than 0.05 except responsiveness factors.

Thus, the regression equation can be written as

CS $=.972+.141 T a+.114 R+.013 R e s+.708 A s s+.161 E$

\section{Conclusions and Recommendations}

\subsection{Conclusions}

* Regarding to the correlation analysis, the researcher proves based on the Pearson correlation result tangibility, reliability, assurance and empathy are significant and positively correlated with the customer satisfaction in insurance company but responsiveness resulted in insignificantly correlated.

* Regarding to the multiple regression analysis the researcher rank the identified factors with the help of standardized beta coefficient as follows. Frome service quality dimensions Assurance is the most influential with the regression coefficients of beta of .640. The next important factor is empathy with the beta of 0.145 and also tangibility and reliability with the beta of 0.119 are important factors towards insurance companies in wolita zone. Responsiveness is not found to have a significant effect on customer satisfaction. The predictors variables of service quality Tangibility, Reliability, Assurance and Empathy were supported, 
therefore, we can conclude that the four service quality dimensions are statistically explaining the variation in customer's satisfaction.

\subsection{Recommendations}

* From the major independent variables considered in the study Assurance has great impact on customer satisfaction in insurance company, this in turn implies that Assurance has highly significant positive association with customer's satisfaction and found a highly affecting customer satisfaction insurance companies in Wolaita zone.

* On another hand the result of study reveals that responsiveness and customer satisfaction should be enhanced by improving quality service and taking good name for insurance company. This makes insurance customers to be more satisfied with the service they have acquired and become devoted to the organization. Therefore the top management of insurance companies should have focus on the service quality while responsiveness has bad impact on customer satisfaction.

\section{REFERENCES}

Anderson. F. (1994) Customer satisfaction, market share and profitability, Journal of International Marketing, Vol.58, no.3, pp. 53-66,

Anderson, E. and Mittal,V. W, (2011) Strengthening the satisfaction profit chain., Journal of Service Research, vol.3, no.2, pp.107-120,

Balaji, M.,2009 Customer Satisfaction with Indian Mobile Services., IUP Journal of Management Research, vol. 8 , no.10, pp.52-62,

Baumann, C., Burton, S. Elliott, G. and Kehr, H., 2007 Prediction of attitude and behavioural intentions in retail insurance ., The International Journal of Insurance Marketing, vol. 25, no.2, pp.102-116,

Conrad, C.A., Brown, G., \& Harmon, H.A. (2007)., Customer satisfaction and corporate culture: A profile deviation analysis of a relationship marketing outcome., Psychology \& Marketing Journal, vol.14,no.7, pp. $663-674$

Ehigie, B. O., 2016 Correlates of customer loyalty to their insurance: A case study in Nigeria, International Journal of Insurance Marketing, vol. 24, no.7, pp.494-508,

Grönroos, C. (1984): A service quality model and its marketing implications: European Journal of Marketing, 18(4): 36-44.

Hokanson, S., (1995) The Deeper You Analyze the More You Satisfy Customers, Marketing News, January 2 , its relationship with satisfaction, Journal of Service Marketing, 14(3), 217-231.

Kang, G.D., James, J., and Alexandris, K. (2002) Measurement of internal service quality: Application of the SERVQUAL battery to internal service quality, Managing Service Quality, Vol.12.

Kotler P., Armstrong G., Saunders J. Wong V. (2002): Principle of Marketing, 3rd edition, Pretence Hall Europe.

Manrai, L.A. \& Manrai, A.K. (2007), A field study of customers' switching behavior for insurance services, Journal of Retailing and Consumer Services,Vol.14, pp.208-15,

Oliver, R.L. (1981) Measurement and evaluation of satisfaction processes in retail settings. Journal of Retailing, 57(3), 25-48.

Reichheld FF \&Sasser WE, (1990), Zero Defections: Quality Comes to Services, Harvard Business Review, September-October, 105-111.

Saunders, M., Lewis P. and Thornhill A. (2009) Research Methods for business students scale for measuring consumer perceptions of service quality, Journal of Retailing, 64 (1), p.12-40.

Sekaran, U. (2003). Research methods for business:Askillbuilding approach (4th edition.) New York: John Wiley.

Molina, A., Martı'n Consuegra, D. and A gueda, E., 2017 Relational benefits and customer satisfaction in retail insurance., International Journal of Insurance Marketing, vol. 25, no. 4,pp. 253-71,

Wood,J.,2008) The effect of buyers'perceptions of environmental uncertainty of satisfaction and loyalty.,Journal of Marketing Theory and Practice, vol. 16 no.4, pp. 30920,

Rust, R.T. And Oliver, R.L. (Eds), 2017 Service Quality: New Directions in Theory and Practice., Sage Thousand Oaks, CA, 1994.

Sharma, N. and Ojha, S., 2014. Measuring service performance in mobile communication., The Service Industries Journal, vol. 24, no. 6, pp. 109-28,

Zaim, H., Bayyurt, N. and Zaim, S., 2010 Service Quality And Determinants Of customer Satisfaction In Hospitals: Turkish Experience., The International Business and Economics Research Journal, vol. 9, no.5, pp. 51-58, 